\title{
Dil Öğretme Öz Yeterlik Ölçeği Geçerlik ve Güvenirlik Çalışması *
}

\author{
Aysel DeregözüiD, İstanbul - Feruzan Gündoğar (iD, İstanbul
}

doi) https://dx.doi.org/10.37583/diyalog.845602

\section{$\ddot{O} z$}

Bu çalışmada, genelde yabancı dil özelde ise Almanca öğretmeni adaylarının dil öğretme öz yeterliklerini belirlemeye yönelik geçerli ve güvenilir bir ölçek geliştirilmesi amaçlanmıştır. Bu amaç kapsamında Dil Öğretme Öz Yeterlik Ölçeği geliştirilmiştir. Veri analizinde PASW Statistics 18 ve LISREL 8.80 programlarında faydalanılmıştır. Ölçeğin geçerlik durumu kapsam ve yapı geçerliği açısından incelenmiş̧ir. Güvenirlik düzeyi ise, tabakalı alfa güvenirlik analizi yöntemi ile belirlenmiştir. Kapsam geçerliği için uzman görüşüne başvurulmuş ve kapsam geçerlik oranına göre uzmanların en az \%75 oranında uyuşma gösterdikleri maddeler ölçekte tutulmuştur. Uzman görüşü sonucunda 45 maddeden oluşan 5'li Likert tipindeki Dil Öğretme Öz Yeterlik Ölçeği taslak formu oluşturulmuştur. Uygulamaya, Marmara Üniversitesi Yabancı Diller Eğitimi Almanca, Fransızca ve İngilizce öğretmenliği programlarında okuyan öğretmen adayları katılmıştır. Uygulamaya 150 öğretmen adayı katılmıştır. Elde edilen veriler açımlayıcı ve doğrulayıcı faktör analizi ile incelenmiştir. Faktör analizi sonucunda madde yük değeri 30 sınırı altında kalan ve faktörlere katkısı olmayan maddeler silinmiş̧tir. Açımlayıcı faktör analizi sonucunda üç boyutlu bir yapının olduğu görülmüştür. Açımlayıcı faktör analizi ile önerilen faktör modeli doğrulayıcı faktör analizi ile de test edilmiştir. RMSEA değeri .08, CFI .97 ve GFI ise .90 olarak hesaplanmıştır. Bu değerler modelin uygun uyum değerlerine sahip olduğunu göstermektedir. Çalışma sonucunda 22 maddelik ve üç boyuttan oluşan Dil Öğretme Öz Yeterlik Ölçeği geliştirilmiştir. Boyutlar içeriklerine uygun olarak planlama, uygulama, ölçme ve değerlendirme boyutları olarak adlandırılmıştır. Çalışma neticesinde yabancı dil öğretmeni adaylarının dil öğretme öz yeterliklerini belirlemede kullanılacak geçerli ve güvenilir bir ölçme aracı geliştirilmiştir.

Anahtar Sözcükler: Dil ögretme, yeterlilik, öz yeterlik, ölçek gelişstirme, geçerlik, güvenirlik.

\section{Abstract}

\section{The Validity and Reliability of the Language Teaching Self Efficacy Scale}

The aim of this study is to develop a valid and reliable scale to measure prospective language teachers' language teaching self - efficacy. For this aim, the Language Teaching Self - Efficacy Scale is developed. The data is analyzed with PASW Statistics 18 and LISREL 8.80 programs. At first, a draft scale consisting of 45 items was developed in the development procedure and experts were asked for their

Einsendedatum: 20.10 .2020

Freigabe zur Veröffentlichung: 31.12.2020

" Bu çalışma, Aysel Deregözü'nün Prof. Dr. Feruzan Gündoğar danışmanlığında hazırladığı "Yapısal Eşitlik Modellemesi ile Dil Öğretme Yetkinliğinin İncelenmesi” adlı doktora tezinin bir bölümüdür. Söz konusu ölçek doktora tezi kapsamında geliştirilmiş olup, ölçek geliştirme sürecinin bir kısmı 23 - 25 Mart 2018 tarihinde gerçekleşen Uluslararası Bilim ve Eğitim kongresinde bildiri olarak sunulmuş ve özet bildiri olarak yayınlanmıştır. 
opinions on the conformity of items in terms of language, expression and content validity. Based on the expert opinions, the items were revised and items, which were not found to be appropriate, were excluded. A draft scale with 30 items was finalized. As next, the validity of the scale is examined with exploratory and confirmatory factor analysis methods. The reliability is determined according to the result of Cronbach alpha value. The draft scale was administered to 150 prospective language teachers in the majors English, French and German language teaching and validity and reliability determined. The analysis revealed that the scale consisted of three factors. The reliability of the scale was evaluated with Cronbach's alpha reliability coefficient for internal consistency. The Cronbach's alpha for the entire scale and the subscales were calculated. The internal consistency coefficient for the entire scale was found to be .85 , for the subscales 'Planning' .59, 'Performing' .89 and 'Evaluating' .88. Based on the analysis results, a scale with 22 items was finalized.

Keywords: Language teaching, competence, self - efficacy, scale development, validity, reliability. 


\section{EXTENDED ABSTRACT}

This study aims to develop a valid and reliable scale to measure prospective language teachers' language teaching self - efficacy. In the accessible literature, studies mostly focus on the measurement of competences acquired during teacher education in the fields of mathematics and science but the measurement of competences in the fields of language teaching and language teacher education has not been studied much. As a result, there seems to be a lack of reliable and valid instruments to measure the development of competences during language teacher education in general and German language teacher education in special.

The sample for this study consists of prospective language teachers studying at the education faculty in the foreign language teaching department of a university in the western part of Turkey. The groups were determined with random sampling method. The data was collected from prospective teachers with three majors (English French and German as a foreign language) during the academic year 2016-2017. The aim of this study is to examine prospective language teachers' language teaching self - efficacy level. For this aim, the Language Teaching Self-Efficacy Scale is used, which is developed by the researcher. The Language Teaching Self - Efficacy Scale consists of the subscales 'Planning', 'Performing' and 'Assessing' containing items, which indicates skills related to these stages. The items were developed with the help of studies and scales concerning self-efficacy and language teaching competences and their measurement. First, a draft scale consisting of 45 items was developed and experts were asked for their opinions on the conformity of items in terms of language, expression and content validity. Based on the expert opinions, the items were revised and items, which were not found to be appropriate, were excluded. A draft scale with 30 items was finalized. A pre - pilot study with 9 participants was conducted to prove whether the draft scale was understandable for the participants in terms of expression. The items, where participants had difficulties were revised. Furthermore, to evaluate participants' demographic features a questionnaire was prepared and used. The form includes also information on the study and, participants' consent is quested with the explanation that the study is based on a voluntary participation. Moreover, the consent of the institution is officially quested and a permission to apply the scale is received.

After that, a study with 150 participants was conducted and structural validity and reliability of the scale was evaluated. The underlying factor structure of the scale was examined with exploratory and confirmatory factor analysis. The analysis revealed that the scale consisted of three factors and items with low factor loadings were excluded from these factors. The reliability of the scale was evaluated with Cronbach's alpha reliability coefficient for internal consistency. After altering items with low reliability coefficients and low item - subscale correlation, the Cronbach's alpha for the entire scale and the subscales were calculated. The internal consistency coefficient for the entire scale was found to be .85 , for the subscales 'Planning' .59 , 'Performing' .89 and 'Evaluating' .88. Based on the analysis results, a scale with 22 items was finalized. Based on the findings of this study, it can be concluded that a reliable and valid scale is developed, which can be used to determine prospective language teachers' language teaching self-efficacy. 


\section{Giriş}

Öğretmen adaylarının mesleki bilgi ve becerileri kazanmalarında öğretmen eğitiminin önemli bir yeri vardır. Eğitim sürecinde, mesleki yeterliliklerin temeli atılmakta ve bu temel üzerine mesleki yetkinlik gelişmektedir (Terhart 2005: 277). Ayrıca, bu süreçte kazanılan yeterlilikler, mesleki yaşamda kullanılmakta ve eğitimin kalitesini belirlemektedir. Öğretmen eğitimi sürecinin bu denli önemli olmas1, bu sürecin izlenmesi ve değerlendirilmesi gerekliliğini ortaya çıkarmaktadır. Alan yazında da, eğitim sürecinde mesleki yeterliliklerin gelişiminin izlenmesi ve ihtiyaç duyulan noktalarda öğrencilere geri dönüt verilmesi önerilmektedir (Zlatkin-Troitschanskaia/ Anand/ Coates 2016: 657). Bu açıdan bakıldığında, henüz eğitimleri devam eden yabancı dil öğretmeni adaylarının da mesleki yeterlilik gelişimlerinin izlenmesi ve gereken noktalarda destekleyici faaliyetlerin yürütülmesi zorunlu görülmektedir.

Ancak, alan yazında iyi bir yabancı dil öğretmenin sahip olması gereken yeterlilikler hakkında farklı görüşler söz konusudur (Königs 2014). Örneğin, Roters, Nold, Haudeck, Keßler ve Stancel-Piqtak (2011: 78), yabancı dil ile ilgili araştırma bulgularına dayanarak, yabancı dil öğretmenlerinin sahip olması gereken bilgi konularını özetlemektedir. Bunlar;

- $\quad$ Yabancı dil edinimi ve öğrenme süreci, kültürlerarası öğrenme

- $\quad$ İçerik ve yapı odaklı yaklaşım

- Hatalara olumlu yaklaşım

- $\quad$ Motivasyon ve öğrenme stratejilerinin öğrenme sürecinde yeri ve önemi

- $\quad$ Sınıf içi iletişim ve öğrenci katılımını sağlama

- $\quad$ Derslerde anadil kullanımının yeri ve önemi

- $\quad$ Almancanın sınıf içi iletişimde yeri ve önemi

- $\quad$ İkidilli eğitimin olumlu etkisi

- $\quad$ Yabancı dil edinim sürecinde ölçme ve değerlendirme

Buna karşılık Leisen (akt. Königs 2014: 73), yabanc1 dil öğretmenlerinin sahip olması gereken yeterlilikleri beş başlık altında ele almaktadır. Bunlar;

- $\quad$ Genel olarak dil ve hedef dil hakkında bilgi sahibi olma

- $\quad$ Yabancı dilin kullanıldığı durumlara uygun dilbilgisine sahip olma

- $\quad$ Yabancı dil öğretiminde yöntem ve teknik

- Yabancı dil düzeyini belirleme ve gelişimini destekleme

- $\quad$ Yabancı dil gelişimi için planlama, uygulama ve değerlendirme 
Königs ise farklı bir yaklaşım sergilemekte ve öğretmen eğitiminde alan, alan öğretimi ve pedagojik olmak üzere üç ana konuda yeterlilik gelişiminin söz konusu olduğunu ve başarılı bir Almanca öğretmenin de bu yeterliliklere sahip olması gerektiğini ifade etmektedir (Königs 2009: 27).

Her ne kadar alan yazında yabancı dil öğretmenlerinin sahip olması gereken yeterlilikler farklı başlıklar altında ele alınmış olsa da, esasında dil ve dil öğretimi konuları ile ilişkili oldukları anlaşılmaktadır (Deregözü 2020: 43). Ancak Königs'in (2014) ifade ettiği gibi, yabancı dil öğretmen yeterlilikleri konusunda alan yazında bir fikir birliği söz konusu değildir. Bu konuya açıklık getirmek amacıyla yürütülen çalışmalar ise, yabancı dil öğretmenleri ile diğer branşlardaki öğretmenler arasındaki bilgi ve beceri farklılıklarını belirlemeye çalışmaktadır. Borg (2006: 5) yaptığ1 incelemede, farklılıkların kaynağını dil ve dil öğretimi ile ilgili bilgi ve becerilere dayandırmaktadır. Nitekim, Baumert ve Kunter de, (2006) "alana özgü bilgi ve becerilerin mesleki yetkinlikte belirleyici" (s. 482) olduğunu vurgulamaktadır. Yabancı dil öğretmenlerinde de alana özgü bilgi ve becerilerin dil ve dil öğretimi konuları ile ilişkili olduğu anlaşılmaktadır.

Ancak Funk'un vurguladığı gibi, "Bütün çabalara rağmen dil öğretmenlerine dil öğretme ve eylemde bulunma becerisi gerektiği gibi öğretilememektedir" (Funk 2003: 69). Bu açıdan bakıldığında, yabancı dil öğretmeni adaylarının eğitimleri sırasında, dil ve dil öğretimi konusunda yeterlilik gelişimlerinin izlenmesi ve onların ihtiyaçlarına uygun eğitim ve öğretim düzenlemelerine gidilmesi ayrı bir önem arz etmektedir. Ancak yabancı dil öğretmeni adaylarının mevcut yeterlilik durumlarını tespit etmek, uygun ölçme araçları ile mümkündür. Alan yazında, öğretmen eğitiminde yeterlilik konusu ile ilgili çalışmaların daha çok matematik öğretmen ve adaylarını kapsadığı, diğer programlarda eğitim gören öğretmen adaylarına yeterince yer verilmediği ifade edilmektedir (Blömeke 2011: 7). Dolayısıyla, kullanılan ölçme araçları da bu gruplara uygun olacak şekilde geliştirilmiştir.

Yabancı dil öğretmeni adaylarında mesleki yeterlilik gelişimini inceleyen çalışmalarda ise, özellikle İngilizce öğretmeni adaylarının yeterlilik gelişimleri üzerinde durulduğu görülmektedir (Blömeke 2013; König/ Lammerding/ Nold/ Strauss/ Tachtoglou 2016; Kirchhoff 2017; Salli-Copur 2008). Almanya'da yürütülen TEDS LT (Öğretmen Eğitimi Gelişimi Araştırması - Öğretmeyi Öğrenme) araştırması incelendiğinde, İngilizce öğretmeni adaylarında alan ve alan öğretimi bilgisi test yardımıyla elde edildiği görülmektedir. Alan bilgisinde, edebiyat, dilbilim ve alan öğretimi bilgisinde yöntem, analiz, süreç, strateji, dil edinimi, edebiyat öğretimi ve kültürlerarası konularda sorular yöneltilmektedir. Bu test, 2009 - 2010 ve 2011 yıllarında Almanya'da sekiz yükseköğretim kurumunda okuyan 882 öğretmen adayına uygulanmıştır (bkz. Blömeke 2013). König, Lammerding, Nold, Rohde, Strauss ve Tachtsoglou'nun (2016) yürüttükleri araştırmada ise, Almanya'da İngilizce öğretmeni adaylarında genel pedagojik içerik bilgisi, içerik bilgisi ve pedagojik içerik bilgisi konularında bilgi düzeyleri incelenmektedir. FALKO-E (Alana özgü öğretmen yeterlilikleri - İngilizce) araştırmasında da, İngilizce öğretmeni adaylarının alan ve alan öğretimi konusunda bilgi düzeyleri test yardımıyla belirlenmeye çalışılmaktadır. $\mathrm{Bu}$ 
kapsamda, dil öğretimi, dilbilim, edebiyat öğretimi ve edebiyat bilim ile kültür bilim konularında test soruları geliştirilmiş ve uygulanmıştır (Kirchhoff 2017: 136).

Almanca öğretmeni adayları ile ilgili yapılan çalışmalarda ise, özellikle ikinci dil olarak Almancanın (Deutsch als Zweitsprache) öğretiminde çok dillilik kapsamında yeterlilik gelişiminin ele alındığ 1 görülmektedir (Koch-Priewe 2018: 7; König/ Doll/ Buchholtz/ Förster/ Kaspar/ Rühl/ Strauss/ Bremerich-Vos/ Fladung/ Kaiser 2018). DaZKom proje çalışmasında, ikinci dil olarak Almanca konusunda öğretmen yeterlilikleri ile ilgili, dil, çok dillilik ve öğretim konularında sorular geliştirilmiştir. Dil yeterliliğini belirlemek için, dilbilgisi, kelime bilgisi ve göstergebilim konularında sorular yöneltilmiş. Çok dillilik için, ikinci dil edinimi ve göç, öğretim konusunda ise, değerlendirme ve geliştirme konularında sorular oluşturulmuştur (Hammer/ Carlso/ Koch-Priewe/ Köker/ Ohm/ Rosenbrock/ Schulze 2015: 35).

Türkiye'de Almanca öğretmeni adaylarının yeterlilik gelişimlerini inceleyen çalışmaların ise, özellikle dilsel yeterlilik gelişimi konusuna yoğunlaştığı görülmektedir (Uluç 2013; Hatipoğlu 2015a; Hatipoğlu 2015b). Almanca öğretmeni adaylarında dil öğretme yeterliliği, pedagojik yeterlilik, alan bilgisi yeterliliği gibi yeterlilik konularında çalışmalara ihtiyaç duyulduğu görülmektedir. Dolayısıyla, yabancı dil olarak Almanca öğretmeni adaylarının eğitim sürecinde yeterlilik gelişimlerini inceleyen çalışmaların yapılması gerekmektedir. Almanca öğretmeni adaylarında yeterlilik gelişimlerini ortaya koyabilmek ise, ancak uygun ölçme araçları ile mümkündür. Gerek İngilizce, gerek Almanca öğretmeni adaylarının yeterlilik durumunu inceleyen çalışmalarda kullanılan ölçme araçları incelendiğinde, dil öğretiminde ana öğretim yeterlilik gelişimine yeterince yer verilmediği de anlaşılmaktadır.

Ana öğretim yeterlilikleri altında yer alan bilgi ve beceriler, Yabancı Dil Öğretmen Adayları İçin Avrupa Portfolyosu (EPOSTL) (Newby/ Allan/ Fenner/ Jones/ Komorowska/ Soghikyan 2004), Yabancı Dil Öğretmenleri İçin Avrupa Profil Tablosu (EPG, 2013) ve Milli Eğitim Bakanlığı tarafından yayınlanan İngilizce Öğretmeni Özel Alan Yeterlilikleri (MEB, 2008) çalışmalarında görülebilir. $\mathrm{Bu}$ çalışmalar incelendiğinde, dil öğretmenleri için gerekli ana öğretim yeterliliklerinin yabancı dil eğitimini planlama, uygulama ve ölçme ve değerlendirme aşamaları altında ele alındıkları görülmektedir (Deregözü 2020: 53). Bu kaynaklar (Newby/ Allan/ Fenner/ Jones/ Komorowska/ Soghikyan 2004; EPG, 2013; MEB 2008) temel alındığında, yabanc1 dil öğretimini planlama, öğrenci ihtiyacını tespit etme, öğrenme hedefini belirleme ve dil öğretimini planlama ve uygulama olarak özetlenebilir. Yabanc1 dil öğretiminde uygulama konusunda gerekli olan yeterlilikler ise, dil öğretimine uygun öğrenme ortamları düzenleme, dil öğrenmesini yönetme/ yönlendirme, sınıf içi etkileşimi sağlama, etkinlik oluşturma, dil düzeyini belirleme ve dilsel gelişimi destekleme, teknik ve strateji kullanma konuları altında ele alınabilir. Bununla birlikte, dilin yapısını öğretme, öğrencilerin dil öğrenme stratejisi geliştirmelerine yardım etme, dil öğretimine uygun yöntem ve teknikleri kullanma, dil öğretim materyali seçme, değerlendirme, uyarlama ve kullanma ile öğrencilerde dilsel becerileri (konuşma, dinleme ve anlama, okuma ve yazma) geliştirmeye yönelik ders hazırlama ve uygulama konularında uygulama yeterliliklerinin gerekli olduğu anlaşılmaktadır. Ölçme ve 
değerlendirme başlığı altında ele alınan yeterliliklerin ise, dil öğrenmeyi ölçme ve değerlendirme, hata analizi yapma ve öğrencilerin dil gelişimlerini belirlemeye yönelik ölçme sonuçlarını yorumlama ve geri bildirim sağlama olarak ele alındıkları görülmektedir (Newby/ Allan/ Fenner/ Jones/ Komorowska/ Soghikyan 2004; EPG, 2013; MEB 2008; akt. Deregözü 2020: 52-53). Ana öğretim yeterlilikleri altında ele alınan bu bilgi ve becerilerin öğretmen eğitimi sürecinde kazanılması gerektiği ve dil öğretme yeterliliğinin göstergeleri oldukları da anlaşılmaktadır.

Öğretmen eğitiminde mesleki yetkinlik durumunu ve yeterliliklerde mevcut düzeyi belirlemek için çeşitli ölçme araçlarının kullanıldığı ifade edilmekte ve yeterlilikleri belirlemede iki yöntemin uygulanması önerilmektedir: Gözlem ve öz değerlendirme. Öz değerlendirme uygulamada sağladığ objektifliğinden dolayı yetkinlik düzeyini belirlemede daha uygun bir yöntem olduğu ifade edilmektedir (Oser/ Curcio/ Düggeli 2007: 17). Kendi kendini değerlendirmeye dayalı test yöntemlerinin öğretmen yeterliliğini ölçme ve değerlendirme konusunda sıklıkla başvurulan bir yöntem olduğu da ifade edilmektedir (Blömeke/ Busse/ Kaiser/ König/ Suhl 2016: 35). Bu çalışmada da, yabancı dil öğretmeni adaylarının dil öğretme yeterlilikleri ana öğretim yeterlilikleri esas alınarak, kendi değerlendirmelerine bağlı olarak gösterecek geçerli ve güvenilir bir ölçeğin geliştirilmesi amaçlanmaktadır.

\section{Amaç}

Alan yazın incelemesi, genelde yabancı dil özelde Almanca öğretmeni adaylarının eğitim sürecinde dil öğretme yeterliliğini ölçebilecek ölçme araçlarına ihtiyaç duyulduğunu göstermektedir. Bu çalışmada, dil öğretme yeterlilik göstergelerini içeren kaynaklar incelenmiş ve genelde yabancı dil özelde ise Almanca öğretmeni adaylarında dil öğretme öz yeterliğini ortaya koyabilecek geçerli ve güvenilir bir ölçme aracının geliştirilmesi amaçlanmıştır. Geliştirilen ölçme aracına ilişkin aşağıdaki araştırma sorularına cevap aranmaktadır:
1. Dil Öğretme Özyeterlik Ölçeğinin geçerlik düzeyi nedir?
2. Dil Öğretme Özyeterlik Ölçeğinin güvenirlik düzeyi nedir?

\section{Önem}

Yabancı dil öğretmeni adaylarının ihtiyaçlarına göre eğitim verilebilmesi ve mesleki yetkinlik gelişimlerinin desteklenebilmesi için, mevcut durumlarının bilinmesi gerekmektedir. Mevcut durumlarının belirlenmesi ise, uygun ölçme araçları ile mümkündür. Ölçme araçlarının geçerli ve güvenilir olması ise bir zorunluluktur. Geçerli ve güvenilir ölçme araçları ile yabancı dil öğretmeni adaylarının yeterlilikleri tespit edilmiş ve ihtiyaca uygun eğitim ve öğretim faaliyetlerinin yürütülmesi olanağ sağlanmış olacaktır. 


\section{Yöntem}

\section{Araştırmanın Modeli}

Çalışma tarama modeline göre düzenlenmiş bir araştırmadır. "Tarama modelleri, geçmişte ya da halen var olan bir durumu var olduğu şekliyle betimlemeyi amaçlayan araştırma yaklaşımlarıdır. Araştırmaya konu olan olay, birey ya da nesne kendi koşulları içinde ve olduğu gibi tanımlanmaya çalışılır. Onları, herhangi bir şekilde değiştirme, etkileme çabası gösterilmez" (Karasar 2009: 76).

\section{Evren ve Örneklem}

Çalışmanın evrenini, Marmara Üniversitesi Yabancı Diller Eğitimi Bölümü, 2016 2017 eğitim öğretim yılında aktif şekilde kayıtlı öğrenciler oluşturmaktadır. Örneklem ise, Almanca, Fransızca ve İngilizce öğretmenliği programlarında okuyan 150 yabancı dil öğretmeni adayıdır. Çalışmada basit seçkisiz örnekleme yöntemi kullanılmıştır. Bu şekilde „her bir örnekleme birimine eşit seçilme olasılığı“ (Büyüköztürk/ Kılıç Çakmak/ Akgün/ Karadeniz/ Demirel 2013: 85) sağlanmıştır.

\section{Veri Toplama Aracının Geliştirilmesi}

Veri toplama aracının geliştirilmesi amacıyla, ilk önce alan yazın dil öğretme yeterliliği konusunda incelenmiş, dil öğretme yeterliliği için gerekli alt beceriler saptanmıştır. Daha sonra ise, bu becerileri yansıtacak maddelerin oluşturulma aşamasına geçilmiştir. Ölçeğin taslak formunda yer alacak maddeler öz yeterlik ifadeleri şeklinde ve 5'li likert tipinde hazırlanmıştır. Ölçeğe verilen yanıtlar „Kesinlikle Katılmıyorum“, „Katılmıyorum“, „Kararsızım“, „Katılıyorum“ ve „Kesinlikle Katılıyorum“ şeklinde beşli derecelendirmeye uygun olacak şekilde oluşturulmuştur.

„Geçerlik, testin bireyin ölçülmek istenen özelliğini diğer özelliklerle karıştırmadan ne derece doğru ölçtügü ile ilgilidir“" (Büyüköztürk/ Kılıç Çakmak/ Akgün/ Karadeniz/ Demirel 2013: 116). Dil Öğretme Öz Yeterlik Ölçeği’nin geçerlik durumu ise, kapsam ve yapı geçerliği açısından incelenmektedir. Kapsam geçerliğini belirlemek için uzman görüşüne dayalı kapsam geçerlik durumu irdelenmektedir. Bu amaçla, Dil Öğretme Öz Yeterlik Ölçeği taslak formunda yer alan maddeler uzman formu hazırlanarak uzman görüşüne sunulmuştur. İçeriğin uygunluğu ile ilgili yabancı diller eğitimi alanında çalışan altı uzmandan, dil açısından uygunluk Türkçe eğitimi alanında çalışan bir uzmandan ve maddelerin uygunluğu ve düzenlenmesi konusunda ise, test geliştirme alanında iki uzmandan görüş alınmıştır. Maddelerin uygunluk düzeyi kapsam geçerlik oranına göre hesaplanmıştır. Uzmanların en az \%75 oranında uyuşma gösterdikleri maddeler ölçekte tutulmuş, uygun bulunmayanlar açıklamalar doğrultusunda ya düzeltilmiş ya da çıkarılmıştır. Buna göre dil öğretme öz yeterliği konusunda geliştirilen 45 maddeden 30'u belirtilen asgari düzeyde uygun görülmüştür. $\mathrm{Bu}$ aşamadan sonra örneklemden 9 katılımcıya ön uygulama yapılmış ve maddelerin anlaş1lırlığg, cevaplama süresi konusunda dönüt alınmıştır. Uygulama için kurumdan 
gerekli izinler alınmış ve katılımcılara, demografik bilgileri içeren bilgi formu ile birlikte Dil Öğretme Öz Yeterlik Ölçeği taslak formu uygulanmıştır. Eğitim ve öğretim yılı dönem sonunda dil öğretme öz yeterlilik durumu saptanmaya çalışıldığında, ölçeğin psikometrik özellikleri tek uygulamaya dayalı olarak incelenmektedir. Elde edilen veriler ile ölçeğin geçerlik ve güvenirlik düzeyi hesaplanmıştır.

\section{Bulgular}

\section{Dil Öğretme Öz Yeterlik Ölçeği Yapı Geçerlik Bulguları}

Yapı geçerliği, „Testten elde edilen puanların test ile ölçülmek istenen kavramın (yapının) gerçekte ne derece ölçülebildiği ile ilgilidir“ (Büyüköztürk/ Kılıç Çakmak/ Akgün/ Karadeniz/ Demirel 2013: 119). Bu çalışmada, ölçek geliştirme çalışmalarında yapı geçerliliğine ilişkin kanıt elde etmek amacıyla en sık kullanılan yöntemlerden biri olan faktör analizi yöntemi kullanılmıştır. „Faktör analizi, birbirleriyle ilişkili çok sayıda değişkeni bir araya getirerek, az sayıda kavramsal olarak anlamlı (faktörler/ yapılar) yeni değişkenler keşfetmeyi (...)“ sağlayan çok değişkenli bir istatistik olarak tanımlanmaktadır (Çokluk/ Şekercioğlu/ Büyüköztürk 2012: 178).

\section{Açımlayıcı Faktör Analizi Bulguları}

Yabancı Dil Öğretme Öz Yeterlik Ölçeği'nin yapı geçerliğini belirlemek amacıyla maddeler arası gruplaşmalar açımlayıcı faktör analizi ile incelenmiştir. Faktör analizi yapılabilmesi için ön koşul olan örneklem yeterliliği, KMO değerine ve maddeler arasında 0.3 'lük korelasyonun bulunup bulunmadığına bakılarak değerlendirilmiştir (Pallant 2005: 178). Çalışmada, KMO değeri 0.93 olarak bulunmuştur. Alan yazında bu değerin en az 0.60 olması gerektiği ifade edilmekte ve $0.80-0.90$ aralığındaki KMO değerlerinin yeterli örneklem büyüklüğüne işaret ettiğini dile getirmektedir (Pallant 2005: 174). Bu değer aralıklarına bakıldığında, örneklem yeterliliğinin çok iyi düzeye karşılık geldiği anlaşılmaktadır. Faktör analizi için diğer bir koşul, verilerin normal dağılım göstermesi gerektiğidir. Normal dağılımın olup olmadığ 1 ise Bartlett testi ile belirlenebilmektedir. Bartlett test değeri 0.00 olarak bulunmuş ve p değerinin 0.05 'den küçük olması verilerin faktör analizi için uygun olduğunu göstermektedir.

$\mathrm{Bu}$ analizlerden sonra faktör sayısını belirlemek amacıyla Başlangıç Temel Bileşenler Analizi yapılmıştır. Analiz sonucu Tablo 1'de yer almaktadır.

\begin{tabular}{cccc}
\hline & \multicolumn{3}{c}{ Öz Değerler } \\
\cline { 2 - 4 } Faktör & Toplam & Varyans Yüzdesi & Toplam Varyans Yüzdesi \\
\hline 1 & 11.25 & 37.49 & 37.49 \\
2 & 5.51 & 5.51 & 43.00 \\
3 & 5.02 & 5.02 & 48.02
\end{tabular}




\begin{tabular}{llll}
4 & 3.86 & 3.86 & 51.88 \\
5 & 3.54 & 3.54 & 55.42 \\
6 & 3.40 & 3.40 & 58.82 \\
\hline
\end{tabular}

Tab. 1: Açımlayıcı Faktör Analizi Başlangıç Temel Bileşenler Analizi Sonucu

Temel Bileşenler Analizi bulguları incelendiğinde (Tablo 1), öz değeri 1'den büyük altı faktörün bulunduğunu göstermektedir. İlk faktör varyansın \% 37.4'ünü açıklarken, altıncı faktörün varyansın \% 3.4'ünü açıkladığı anlaşılmaktadır. Faktörlerin toplam varyansı açıklama gücü \% 58.8'dir. Faktörlerin varyans yüzdelerine bakılınca, ilk üç faktörün diğer faktörlere göre daha güçlü oldukları görülmektedir.

Ancak kesin faktör sayısını belirlemek için Yamaç Eğim testi ve O'Connor (2000) Paralel Analiz yöntemi kullanılmıştır. Yamaç Eğim testi saçılma diyagramında kırılma noktası Şekil 1'de yer almaktadır.

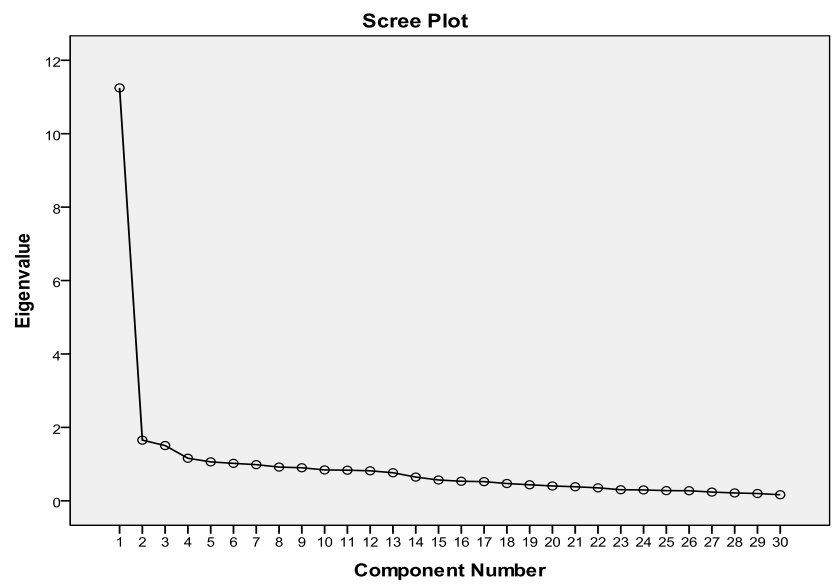

Şek. 1: Dil Öğretme Öz Yeterlik Ölçeği Yamaç - Eğim Grafiği

Yamaç - Eğim grafiğinde (Şekil 1) kırılma noktası incelendiğinde, bunun üçüncü faktörden sonra gerçekleştiği görülmektedir. Dolayısıyla, üç faktörlü bir yapının olduğu düşünülmektedir. Hayton, Allen ve Scarpello'nun (2004) belirttiği üzere, Kaiser kriteri ve saçılma grafiğine bakılarak kesin faktör sayısına bakmak yetersiz kalmakta ve Paralel testlerin uygulanması daha uygun görülmektedir.

Ölçeğin kesin faktör sayısına karar vermek amaciyla O’Connor (2000) Paralel test yöntemi uygulanmıştır. Paralel test sonucu elde edilen değerler, varyans öz değerleri ile karşılaştırılmış ve paralel test öz değerleri varyans öz değerlerinden küçük olan faktörler kesin faktörler olarak belirlenmiştir. Paralel test bulguları Tablo 2'de yer almaktadir. 


\begin{tabular}{lcc}
\hline Faktör & Açıklanan Toplam Varyans Öz değeri & Paralel Test Öz Değeri \\
\hline 1 & 13.391 & 1.9452 \\
2 & 2.169 & 1.8036 \\
3 & 1.924 & 1.6975 \\
4 & 1.284 & 1.6116 \\
5 & 1.212 & 1.5313 \\
6 & 1.088 & 1.4591 \\
\hline
\end{tabular}

Tab. 2: Açıklanan Toplam Varyans Öz Değeri ve Paralel Test Öz Değeri Bulguları

Tablo 2 incelendiğinde, ilk üç faktörün paralel test öz değeri varyans öz değerinden küçüktür. Dolayısıyla, üç faktörlü bir yapının olduğuna karar verilmiştir.

\section{Dil Öğretme Öz Yeterlik Ölçeği Madde ve Faktör Yük Değerleri Bulguları}

Faktör yük değerleri maddelerin alt boyutlarla olan ilişkisini açıklayan bir katsayıdır. Alt kesme noktası olarak 0.3 veya 0.4 değeri alınmaktadır (Büyüköztürk/ Kılıç Çakmak/ Akgün/ Karadeniz/ Demirel 2013: 123). Dolayısıyla, madde yükünün en az -/+ 0.3'ün üzerinde olması gerekmektedir. $\mathrm{Bu}$ değerin altında olan madde yükleri analiz dışı tutulmaktadır. Madde yük değerleri, Varimax dik döndürme analizi sonucuna bakılarak incelenmiştir. 2., 3., 4., 5., 6., 8., 10. ve 11. maddeler yük değerleri düşük bulunarak analiz dışı bırakılmıştır. Maddelerin faktörler altındaki dağılımları Tablo 3'de görülebilir.

\begin{tabular}{|c|c|c|}
\hline \multirow[t]{2}{*}{ Madde } & \multicolumn{2}{|r|}{ Faktör Yükü } \\
\hline & Faktör 1 & Faktör 2 \\
\hline 24. Dil öğretiminde işbirlikli öğrenme yöntem ve teknikleri kullanabilirim. & .76 & \\
\hline 25. Dil öğretiminde eylem odaklı öğrenme yöntem ve teknikleri kullanabilirim. & .75 & \\
\hline $\begin{array}{l}\text { 18. Öğrencilerin dil gelişim durumlarına göre yöntem ve teknikler } \\
\text { kullanabilirim. }\end{array}$ & .67 & \\
\hline 23. Dil öğretimi için proje etkinlikleri hazırlayabilirm. & .66 & \\
\hline $\begin{array}{l}\text { 19. Öğrencilerin iletişim becerisini geliştirecek öğretim yöntem ve teknikleri } \\
\text { kullanabilirm. }\end{array}$ & .66 & \\
\hline 20. Dil öğretimi için özgün etkinlikler hazırlayabilirim. & .62 & \\
\hline 26. Öğrencilerin dil gelişimlerini ölçen yöntem ve teknikleri kullanabilirim. & .60 & \\
\hline 17. Öğrenci merkezli öğretim yöntem ve teknikleri kullanabilirim. & .57 & \\
\hline 12. Çocuklara yönelik ders materyalleri hazırlayabilirim. & & .81 \\
\hline 13. Gençlere yönelik ders materyalleri hazırlayabilirim. & & .74 \\
\hline 14. Dil öğretimine yönelik özgün materyaller geliştirebilirim. & & .66 \\
\hline 21. Çocuklara yönelik etkinlikler hazırlayabilirim. & & .64 \\
\hline 22. Gençlere yönelik etkinlikler hazırlayabilirim. & & .61 \\
\hline 16. Öğrencilerin farklı ihtiyaçlarına göre ders materyalleri hazırlayabilirim. & & .59 \\
\hline
\end{tabular}




\begin{tabular}{lcc}
\hline 15. Dilde iletişim becerisini geliştirecek materyaller hazırlayabilirim. & .58 \\
\hline 9. Ders kitaplarından faydalanılarak ders işleyebilirim. & .46 \\
\hline 7. Bütün öğrencilerin derse katıulımını sağlayacak sınıf düzenini oluşturabilirim. & .45 \\
\hline 1. Dil öğretim programına uygun ders planlayabilirim. & .42 \\
\hline $\begin{array}{l}\text { 28. Dört dil becerisini (konuşma, dinleme, okuma, yazma) ölçen yöntem ve } \\
\text { teknikleri kullanabilirim. }\end{array}$ & .79 \\
\hline 29. Öğrencilere dilsel durumlarına uygun geribildirim verebilirim. & .77 \\
\hline 30. Öğrencilerin öğrenme durumlarını ölçen yöntem ve teknikleri kullanabilirim. & .72 \\
\hline 27. Dil derslerinin etkili olup olmadı̆̆ını değerlendirebilirim. & .66 \\
\hline
\end{tabular}

Tab. 3: Dil Öğretme Öz Yeterlik Ölçeği Pilot Çalışma Faktör Yük Değerleri

Madde yük değerleri incelendiğinde (Tablo 3), en düşük değerin 0.42 , en yüksek değerin 0.81 olduğu görülmektedir. Birden fazla faktörde yüksek değer veren madde bulunmamaktadır. Faktörler altında bulunan maddeler incelendiğinde, kuramsal yapıya uygun bir şekilde yer aldıkları görülmektedir.

Üç boyut altında dağılan maddeler, ölçek alt boyut maddeleri olarak kabul edilmiştir. Madde çıkarılması sonucunda varyans oranları tekrar incelenmiş ve ilk üç faktörün varyansı açıklama oranının $\% 62$ olduğu görülmüştür. Asgari \%50 varyans açıklama oranı koşuluna göre uygun bir oran olduğu anlaşılmaktadır.

\section{Doğrulayıcı Faktör Analizi Bulguları}

Açımlayıcı faktör analizi sonucu elde edilen yapının doğrulanması amacıyla doğrulayıcı faktör analizi uygulanmıştır. „Doğrulayıcı faktör analizi ile önceden kurulan modelin bazı parametreler açısından doğruluğu test edilir“ (Çokluk/ Şekercioğlu/ Büyüköztürk 2012: 282), bunun yanı sıra doğrulayıcı faktör analizi „ölçme aracının gizil yapısını incelemek için ölçek geliştirme süreci boyunca kullanılmaktadır“ (Brown, 2006; akt. Çelik/ Y1lmaz 2013: 43).

Dil Öğretme Öz Yeterlik Ölçeğinde maddelerin altboyutlarda dağılımını gösteren doğrulayıcı faktör analizi sonucu Şekil 2'de görülmektedir. 


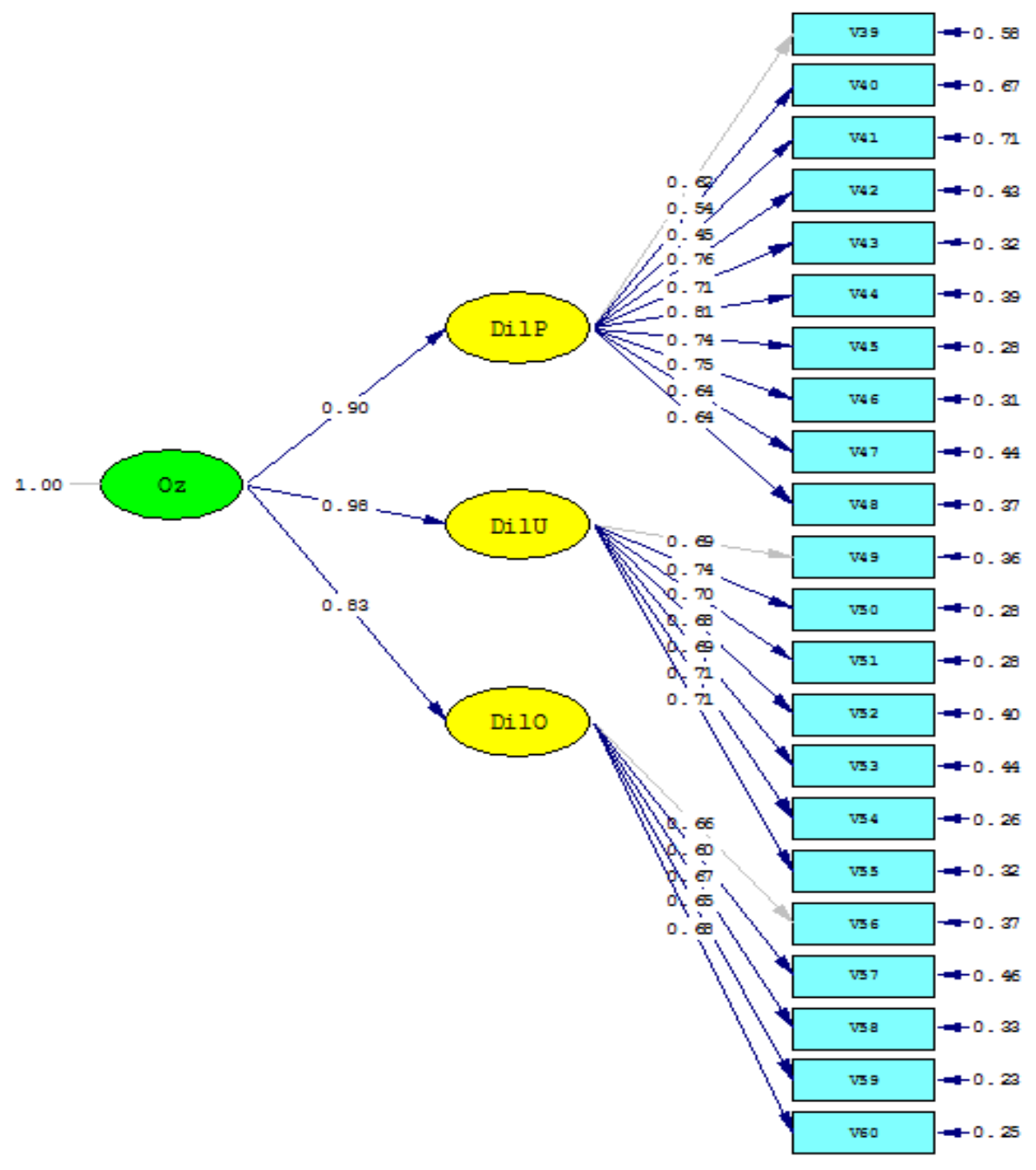

Şek. 2: Dil Öğretme Öz Yeterliği Ölçeği Doğrulayıc1 Faktör Analizi Sonucu

Doğrulayıcı faktör analizinde standartlaştırılmış yükler incelendiğinde. 05 'in altında değer bulunmamaktadır. Bu aşamadan sonra doğrulayıcı faktör analizinden elde edilen uyum ölçütlerine bakılmıştır. Dil Öğretme Öz Yeterlik Ölçeği’nin doğrulayıcı faktör analizi uyum değerleri, Çokluk, Şekercioğlu ve Büyüköztürk'ün (2012: 271-272) belirttiği kriterler doğrultusunda değerlendirilmiş ve uyum ölçütlerinin uyum düzeyleri belirlenmiştir. Tablo 4, doğrulayıcı faktör analizi uyum değerlerini göstermektedir. 


\begin{tabular}{ccc}
\hline Uyum Ölçütü & Değeri & Uyum \\
$\chi \chi^{2}$ & 879.78 & Orta Düzeyde Uyum \\
RMSEA & 4.27 & İyi Uyum \\
CFI & .08 & Mükemmel Uyum \\
SRMR & .97 & Mükemmel Uyum \\
NFI & .04 & Mükemmel Uyum \\
GFI & .96 & İyi Uyum \\
AGFI & .90 & Kötü Uyum
\end{tabular}

Tab. 4: Dil Öğretme Öz Yeterlik Ölçeği Doğrulayıcı Faktör Analizi Uyum Değerleri

Doğrulayıcı faktör analizinde uyum değerleri incelendiğinde (Tablo 4), Ki-Kare testi sonucunun serbestlik derecesine oranının 4.27 olduğu, değerin 5 altında olması ile orta düzeyde uyumlu olduğu anlaşılmaktadır. RMSEA değerinin .10 dan küçük olması kabul edilebilir aralıkta bulunduğunu göstermektedir. CFI değerinin .97 olması ise, iyi uyumu göstermektedir (CFI $\geq .97)$. Elde edilen değerler kuramsal çerçeve göz önünde bulundurularak ele alındığından, uyum düzeyinin artırılması konusunda herhangi bir modifikasyon işlemi yapılmamıştır.

\section{Dil Öğretme Öz Yeterlik Ölçeği Güvenirlik Bulguları}

"Güvenirlik, testin ölçmek istediği özelliği ne derece doğru ölçtüğü ile ilgilidir“ (Büyüköztürk/ Kılıç Çakmak/ Akgün/ Karadeniz/ Demirel 2013: 109). Ölçme aracının güvenirliği iki ayrı yöntem uygulanarak saptanmıştır. Birinci yöntem uzman görüşlerine başvurulması ve geliştirilen maddelerin ölçülmek istenileni ne derece yeterli ölçtügüune dair görüşlerin alınmasıdır. Uzmanların uygun buldukları maddeler güvenilir olarak saptanmıştır. Dolayısıyla, içerik açısından uygun bulunan maddeler güvenilir olarak değerlendirilmiştir. İkinci yöntem ise, Cronbach alfa güvenirlik analizinin yapılmasıdır. Dil Öğretme Öz Yeterlik Ölçeği'nin Cronbach alfa iç tutarlılık katsayısı .85 bulunmuştur. Alt boyutlara göre bu katsayı, planlama boyutunda .59, uygulama boyutunda .89 ve ölçme ve değerlendirme boyutunda .88 olarak belirlenmiştir. Bu değerlere göre, ölçek iyi düzeyde güvenilir olduğu anlaşılmaktadır.

\section{Sonuç}

$\mathrm{Bu}$ çalışmada, genelde yabancı dil özelde Almanca öğretmeni adaylarının dil öğretme yeterlilik durumlarını öz yeterliklerine bağlı değerlendirmek amacıyla geliştirilen Dil öğretme Öz Yeterlik Ölçeği’nin psikometrik özellikleri incelenmiştir. Alan yazın yardımıyla ve uzman görüşleri alınarak oluşturulan maddelerin geçerlik ve güvenirlik düzeyleri hesaplanmıştır. Geçerlik ve güvenirliği etkileyen maddeler taslak ölçekten çıkarılmış ve nihai ölçek oluşturulmuştur. Yapı analizi sonucunda üç boyutlu bir 
yapının söz konusu olduğu anlaşılmış ve alan yazında ana öğretim yeterlilikleri ve madde içerikleri göz önünde bulundurularak, alt boyutlar Planlama, Uygulama ve Ölçme ve Değerlendirme olarak adlandırılmıştır. Nihai ölçekte 22 madde bulunmaktadır. Yapılan çalışma ile, genelde yabancı dil özelde ise Almanca öğretmeni adaylarının dil öğretme öz yeterliğini ortaya koyabilecek geçerli ve güvenilir bir ölçme aracının geliştirilmiş olduğu görülmektedir. Alan yazında dil öğretmeni adaylarının yeterliliklerinin belirlenmesi konusunda ölçme araçlarına duyulan ihtiyaç göz önünde bulundurulduğunda, bu çalışmanın alana katkı sunması ve başka çalışmalara 1 şı tutmasi arzulanmaktadir.

\section{Kaynakça}

Baumert, Jürgen/ Kunter, Mareike (2006): Stichwort: Professionelle Kompetenz von Lehrkräften. Zeitschrift für Erziehungswissenschaft, 9 (4), 469-520.

Blömeke, Sigrid (2011): Teacher education and development study: Learning to teach (TEDS - LT) Erfassung von Lehrerkompetenzen in gering strukturierten Domänen. In: S. Blömeke, A. Bremerich - Vos, G. Kaiser, G. Nold, H. Haudeck, J.U.Keßler, K. Schwippert, \& H.Willenberg (Hrsg.): Kompetenzen von Lehramtstudierenden in gering strukturierten Domänen. Erste Ergebnisse aus TEDS - LT. Münster, New Jork, München, Berlin: Waxmann Verlag, 7-24.

Blömeke, Sigrid (2013): Einleitung: Professionelle Kompetenzen im Studienverlauf. In: S. Blömeke, A. Bremerich-Vos, G. Kaiser, G. Nold, H. Haudeck, J.-U. Keßler, K. Schwippert (Hrsg.): Professionelle Kompetenzen im Studienverlauf Weitere Ergebnisse zur Deutsch Englisch und Mathematiklehrerausbildung aus TEDS LT. Münster, New York, München, Berlin: Waxmann Verlag, 7-24.

Blömeke, Sigrid/ Busse, Andreas/ Kaiser, Gabriele/ König, Johannes/ Suhl, Ute (2016): The relation between content - specific and general teacher knowledge and skills. Teaching and Teacher Education, 56, 35 - 46 .

Borg, Simon (2006): The distinctive characteristics of foreign language teachers. Language Teaching Research, 10(1), 3-31.

Büyüköztürk, Şener/ Kılıç Çakmak, Ebru/ Akgün, Özcan Erkan/ Karadeniz, Şirin/ Demirel, Funda (2013): Bilimsel Araştırma Yöntemleri, Geliştirilmiş 15. Baskı, Pegem Akademi: Ankara.

Çelik, H. Eray/ Yılmaz, Veysel (2013): Lisrel 9.1 ile Yapısal Eşitlik Modellemesi. Temel Kavramlar Uygulamalar - Programlama. Yenilenmiş 2. Baskı. Anı Yayıncılık: Ankara.

Çokluk, Ömay/ Şekercioğlu, Güçlü/ Büyüköztürk, Şener (2012): Sosyal Bilimler İçin Çok Değişkenli Ístatistik SPSS ve LISREL Uygulamaları. 2. Bask1. Pegem Akademi: Ankara.

Deregözü, Aysel (2020): Yapısal Eşitlik Modellemesi İle Yabancı Dil Öğretme Yetkinliğinin İncelenmesi. Yayınlanmamış Doktora Tezi. Marmara Üniversitesi Eğitim Bilimleri Enstitüsü İstanbul.

Deregözü, Aysel (2020): Geçmişten günümüze Almanca öğretmenliği lisans programlarına ilişkin karşılaştırmalı bir çalışma. Diyalog Interkulturelle Zeitschrift für Germanistik, 143 - 161.

European Profiling Grid (EPG) (2013): Das Europäische Profilraster für Sprachlehrende. http://www.epgproject.eu/raster/?lang=de (Erişim Tarihi 17.03.2018).

Funk, Hermann (2003): Fremdsprachenlehrerausbildung - von Reform zu Reform rückwärts? In: K. - R. Bausch, F. G. Königs, \& H. - J. Krumm (Hrsg.): Fremdsprachenlehrerausbildung. Tübingen: Gunter Narr Verlag, 143 - 149. 
Hammer, Svenja/ Carlson, Sonja, A./ Ehmke, Timo/ Koch-Priewe, Barbara/ Köker, Anne/ Ohm, Udo/ Rosenbrock, Sonja/ Schulze, Nina (2015): Kompetenz von Lehramtsstudierenden. In Deutsch als Zweitsprache: Validierung des GSL-Testinstruments. Zeitschrift für Pädagogik, 61. Beiheft, 32-54.

Hatipoğlu, Sevinç (2015a): Darstellung der fremdsprachlichen Kompetenzen der angehenden türkischen Deutschlehrer: Beispiel Istanbul Universität. Studien zur deutschen Sprache und Literatur, 63- 76.

Hatipoğlu, Sevinç (2015b): Vergleich der Ergebnisse eines Projekts mit den Selbtseinschätzungender angehenden türkischen Deutschlehrer in Bezug auf die Schreibkompetenz: Beispiel Istanbul Universität. Diyalog Interkulturelle Zeitschrift für Germanistik, 2, 44 -56.

Hayton, James C./ Allen, David G./ Scarpello, Vida (2004): Factor retention decisions in exploratory factor analysis: A tutorial on parallel analysis. Organizational Research Methods, 7(2), 191-205.

Karasar, Niyazi (2009): Bilimsel araştırma yöntemi. 19. Baskı, Ankara: Nobel Yayın Dağıtım.

Kirchhoff, Petra (2017): FALKO-E: Fachspezifisches professionelles Wissen von Englischlehrkräften. Entwicklung und Validierung eines domänenspezifischen Testinstruments. In S. Krauss, A. Lindl, A., Schilcher, M. Fricke, A. Göhring, B. Hofmann et al. (Hrsg.): Fachspezifische Lehrerkompetenzen. Konzeption von Professionswissenstests in den Fächern Deutsch, Englisch, Latein, Physik, Musik, Evangelische Religion und Pädagogik. Münster: Waxmann, 113-152.

Koch-Priewe, Barbara (2018): Das DaZKom-Projekt - ein Überblick. In: T. Ehmke, S. Hammer, A. Köker, U. Ohm, \& B. Koch-Priewe (Hrsg.). Professionelle Kompetenzen angehender Lehrkräfte im Bereich Deutsch als Zweitsprache, Münster: Waxmann, 7-38.

König, Johannes/ Doll, Jörg/ Buchholtz, Nils/ Förster, Sabrina/ Kaspar, Kai/ Rühl, Anna-Maria/ Strauß, Sarah/ Bremerich-Vos, Albert/ Fladung, Ilka/ Kaiser, Gabriele (2018): Pädagogisches Wissen versus fachdidaktisches Wissen? Struktur des professionellen Wissens bei angehenden Deutsch-, Englisch- und Mathematiklehrkräften im Studium. Zeitschrift für Erziehungswissenschaft, 21(3), 611-648.

König, Johannes/ Lammerding, Sandra/ Nold, Günter/ Rohde, Andreas/ Strauß, Sarah/ Tachtsoglou, Sarantis (2016): Teachers' professional knowledge for teaching English as a foreign language: Assessing the outcomes of teacher education. Journal of Teacher Education, $67(4), 320-337$.

Königs, Gerhard Frank (2009): Zwischen Hoffen und Bangen. Möglichkeiten und Grenzen einer europäischen Studienreform am Beispiel des Faches Deutsch als Fremdsprache. Tagungsdokumentation zum Syposium Perspektiven zur Neustruktierung der Studiengänge Deutsch als Fremdsprache in Südosteuropa, İstanbul, 21 -41.

Königs, Gerhard Frank (2014): War die Lernerorientierung ein Irrtum? Der Fremdsprachenlehrer im Kontext der Sprachlehrforschung. FluL, 43(1), 66-80.

MEB (2008): Öğretmen yeterlikleri. Öğretmenlik mesleği genel ve özel alan yeterlikleri. Ankara: Devlet Kitaplar1.

Newby, David/ Allan, Rebecca/ Fenner, Anne-Brit/ Jones, Bary/ Komorowska, Hanna/ Soghikyan, Kristine (2004): Europäisches Portfolio für Sprachlehrende in Ausbildung. Ein Instrument zur Reflexion,http://www.ecml.at/mtp2/fte/html/FTE_E_Results.htm (Erişim Tarihi: 25.11.2016).

O'Connor, Brian P. (2000): SPSS and SAS programs for determining the number of components using parallel analysis and Velicer's MAP test. Behavior Research Methods, Instrumentation, and Computers, 32, 396-402.

Oser, Fritz/ Curcio Gian-Paolo/ Düggeli Albert (2007): Kompetenzmessung in der Lehrerbildung als Notwendigkeit - Fragen und Zugänge. Beiträge zur Lehrerbildung, 25 (1), 14 -26. 
Pallant, Julie (2005): SPSS survival manual. Sydney: Allen and Unwin.

Roters, Bianca/ Nold, Günter/ Keßler, Jörg-U./ Stancel-Piqtak, Agnes (2011): Professionelles Wissen von Studierenden des Lehramts Englisch. In: S. Blömeke, A. Bremerich -Vos, H. Haudeck, G. Kaiser, G. Nold, K. Schwippert \& H. Willenberg (Hrsg). Kompetenzen von Lehramtstudierenden in gering strukturierten Domänen. Erste Ergebnisse aus TEDS - LT, Münster: Waxmann Verlag, 77 - 99 .

Salli-Copur, Deniz (2008): Teacher effectiveness in initial years of service: A case study on

the graduates of METU language education program. (Unpublished doctoral dissertation). Middle East Technical University, Ankara.

Terhart, Ewald (2005): Standards für die Lehrerbildung - Ein Kommentar. Zeitschrift für Pädagogik, $51(2), 275-279$.

Uluç, Fatih (2013): Comparing the language skills and grammatical competences of German language teacher trainees. Procedia, Socail and Behavioral Sciences, 70, 1740 - 1747.

Yener, Hüseyin (2007): Personel performansına etki eden faktörlerin Yapısal Eşitlik Modeli (YEM) ile incelenmesi ve bir uygulama. Yayınlanmış Doktora Tezi. Gazi Üniversitesi. Fen Bilimleri Enstitüsü. Ankara.

Zlatkin-Troitschanskaia, Olga/ Pant, Hans Anand/ Coates, Hamish (2016): Assessing student learning outcomes in higher education: challenges and international perspectives. Assessment \& Evaluation in Higher Education, 41(5), 655-661. 